\title{
Glutamate Transporters Contribute to the Time Course of Synaptic Transmission in Cerebellar Granule Cells
}

\author{
Linda S. Overstreet, Gregory A. Kinney, Ying-Bing Liu, Daniela Billups, and N. Traverse Slater \\ Department of Physiology, Northwestern University Medical School, Chicago, Illinois 60611
}

Transporters are thought to assist in the termination of synaptic transmission at some synapses by removing neurotransmitter from the synapse. To investigate the role of glutamate transport in shaping the time course of excitatory transmission at the mossy fiber-granule cell synapse, the effects of transport impairment were studied using whole-cell voltage- and currentclamp recordings in slices of rat cerebellum. Impairment of transport by L-trans-pyrrolidine-2,4-dicarboxylate (PDC) produced a prolongation of the decay of the AMPA receptormediated current after a repetitive stimulus, as well as prolongation of single stimulus-evoked EPSCs when AMPA receptor desensitization was blocked. PDC also produced a prolongation of both single and repetitive-evoked NMDA receptormediated EPSCs. Enzymatic degradation of extracellular glutamate did not reverse the PDC-induced prolongation of AMPA receptor-mediated current after a repetitive stimulus, suggest- ing that transporter binding sites participate in limiting glutamate spillover. In current-clamp recordings, PDC dramatically increased the total area of the EPSP and the burst duration evoked by single and repetitive stimuli. These data indicate that glutamate transporters play a significant role in sculpting the time course of synaptic transmission at granule cell synapses, most likely by limiting the extent of glutamate spillover. The contribution of transporters is particularly striking during repetitive stimulus trains at physiologically relevant frequencies. Hence, the structural arrangement of the glomerulus may enhance the contribution of transporters to information processing by limiting the extent of glutamate spillover between adjacent synapses.

Key words: glutamate transport; synaptic transmission; cerebellum; reuptake; transporters; time course
At glutamatergic synapses in the CNS, the kinetics of EPSCs are determined by postsynaptic receptor properties and the time course of the glutamate concentration transient. At typical smalldiameter synapses, glutamate diffuses out of the cleft rapidly, within milliseconds (Clements et al., 1992; Clements 1996). The rapid clearance of synaptically released glutamate may be promoted by glutamate transporters, which have been shown to buffer the free glutamate concentration in the cleft within a millisecond after release at cultured hippocampal synapses (Tong and Jahr, 1994; Diamond and Jahr, 1997). Glutamate binding to transporters may also significantly limit the amount of spillover that occurs between neighboring synapses (Asztely et al., 1997; Barbour and Häusser, 1997). Hence, in addition to playing an essential role in the prevention of excitotoxicity by the maintenance of low extracellular glutamate levels, glutamate transporters may have an important role in modulating the time course of synaptic transmission.

However, the effects of transport inhibition on glutamatergic EPSCs are varied. The failure of reuptake blockers to signifi-

Received Jan. 11, 1999; revised Aug. 18, 1999; accepted Aug. 24, 1999.

This work was supported by National Institutes of Health Grants DC002764 and NS34840 to N.T.S. We are grateful to Drs. Susan Amara and David Attwell for helpful discussions and to Dr. Tom Otis for critical reading of this manuscript.

Correspondence should be addressed to Dr. N. Traverse Slater, Department of Physiology, Northwestern University Medical School, 303 East Chicago Avenue, Chicago, IL 60611. E-mail: n-slater@nwu.edu.

Dr. Overstreet's present address: Vollum Institute, Oregon Health Sciences University, Portland, OR 97201.

Dr. Kinney's present address: Department of Physiology and Biophysics, University of Washington, Seattle, WA 98195.

Dr. Liu's present address: Department of Physiology, West China University of Medical Sciences, Chengdu, Sichuan 610041, People's Republic of China.

Copyright (C) 1999 Society for Neuroscience $0270-6474 / 99 / 199663-11 \$ 05.00 / 0$ cantly prolong AMPA receptor-mediated synaptic currents at some synapses (Hestrin et al., 1990; Isaacson and Nicoll, 1993; Sarantis et al., 1993) has been interpreted as evidence that the clearance of glutamate from the synapse is not assisted by transporters. However, when AMPA receptor desensitization is blocked, transport inhibition prolongs the EPSC time course (Mennerick and Zorumski, 1994), indicating that AMPA receptor desensitization may mask the enhancement of the glutamate transient produced by transporter inhibition. Furthermore, transporters contribute to the time course of AMPA receptormediated EPSCs at synapses with multiple release sites, such as the mossy fiber (MF)-unipolar brush cell synapse (Kinney et al., 1997), the calyceal synapse (Otis et al., 1996), and synapses in the inner retina (Matsui et al., 1999). Transport inhibition also prolongs AMPA receptor-mediated EPSCs in cerebellar Purkinje cells, where significant "crosstalk" may occur between densely packed terminals (Barbour et al., 1994; Takahashi et al., 1995).

At the MF-granule cell (GC) synapse in the cerebellum, transport inhibition has been shown to have no effect on the time course of the AMPA receptor-mediated EPSC (Sarantis et al., 1993). However, it has been suggested that the cerebellar glomerulus is specialized to promote spillover (Wall and Usowicz, 1997; Rossi and Hamann, 1998), which implies that transporters may be more important than previously recognized. Although MF-GC synapses have a small diameter postsynaptic density, the glomerulus that encompasses them is one of the most complex arrangements of synaptic contacts in the CNS (Jakab and Hámori, 1988). The core of the glomerulus consists of a large MF terminal that forms a synaptic nest with 100-150 synaptic contacts of $\sim 50$ different GC dendritic digits (Jakab and Hámori, 1988; Jakab, 1989). The plexus of dendritic processes that surround the MF 
terminal is delimited by a sheath of astrocytic membrane in which GLT-1 and GLAST subtypes of glutamate transporters are concentrated (Chaudhry et al., 1995). The goal of this work was to examine the role of glutamate transporters in shaping the time course of synaptic transmission within the glomerulus.

Preliminary reports of some of these results have been presented (Slater and Kinney, 1996; Overstreet et al., 1997).

\section{MATERIALS AND METHODS}

Preparation of brain slices. Experiments were conducted on Sprague Dawley rats of either sex, aged 8-20 d postnatal. The methods for the preparation of thin brain slices and patch-clamp recording of visually identified granule cells in thin cerebellar slices used were similar to those previously described (Silver et al., 1992; D'Angelo et al., 1993; Ebralidze et al., 1996). Animals were anesthetized using isoflurane by inhalation and killed by decapitation using a guillotine while under general anesthesia. The brain was removed by dissection and placed in a chilled $\left(0-5^{\circ} \mathrm{C}\right)$ extracellular solution of the following composition $(\mathrm{mM}): \mathrm{NaCl}$ 126, $\mathrm{KCl} 3, \mathrm{CaCl}_{2} 2.5, \mathrm{MgSO}_{4} 1.3, \mathrm{NaH}_{2} \mathrm{PO}_{4} 1.25, \mathrm{NaHCO}_{3} 26$, and D-glucose 10 (gassed with $95 \% \mathrm{O}_{2}$ and $5 \% \mathrm{CO}_{2}, \mathrm{pH} 7.4$; osmolarity adjusted to $310 \mathrm{mOsm})$. Thin (150- $\mu \mathrm{m}$-thick) parasagittal slices of cerebellar vermis were cut using a vibrating tissue chopper (Vibratome). Slices were maintained at room temperature after the initial hour of incubation until needed for recording.

For recording, slices were transferred to a submersion chamber mounted on the stage of an upright microscope (Leitz Laborlux) and viewed with a Zeiss $40 \times(0.75 \mathrm{NA})$ water-immersion objective with Hoffman Contrast Optics or an Olympus BX50WI upright microscope fitted with a $40 \times(0.80 \mathrm{NA})$ water-immersion objective with Nomarski Optics. The slices were continuously perfused throughout the experiment with external medium at room temperature $\left(20-22^{\circ} \mathrm{C}\right)$. All recordings were made from granule cells in the granular layer of vestibular regions of the cerebellar vermis (nodulus and ventral uvula).

Patch-clamp recording and synaptic stimulation. Patch recording pipettes were fabricated from thick-walled borosilicate glass capillaries (DC resistance 5-10 $\mathrm{M} \Omega$ when filled with internal solution) using a Flaming-Brown horizontal pipette puller (model P-87; Sutter Instruments, Novato, CA). In the majority of experiments, electrodes were filled with an internal solution containing (in $\mathrm{mM}$ ): cesium methanesulphonate 145, QX-314 10, $\mathrm{MgCl}_{2}$ 2, $\mathrm{K}_{2} \mathrm{ATP}$ 5, EGTA 0.1, and HEPES 5, pH 7.2; osmolarity adjusted to $280 \mathrm{mOsm}$. Patch pipettes were mounted in the headstage input of a stage-mounted micromanipulator and positioned over the soma of the neuron by visual control. Transmembrane voltage and current were recorded using an Axopatch 1D or 200B amplifier (filtered at $5 \mathrm{kHz} ;-3 \mathrm{~dB}$ ), stored on video tape (VR-10C; Instrutec), and played back off-line for analysis using pClamp (version 6.0.1) software (Axon Instruments, Foster City, CA) running on a personal computer-compatible 486 or Pentium II microcomputer (Dell). Conventional methods for whole-cell recording of visually identified cells (Hamill et al., 1981; Edwards et al., 1989) were used. The reference electrode was connected to the bath by means of a KCl-agar bridge. All experiments were conducted at a holding potential of $-70 \mathrm{mV}$, unless otherwise noted.

Concentric bipolar tungsten stimulating electrodes (Rhodes) were placed in the white matter to activate MF inputs to granule cells. Stimuli of $100 \mu \mathrm{sec}$ duration were delivered in the presence of bicuculline $(10 \mu \mathrm{M})$ to block $\mathrm{GABA}_{\mathrm{A}}$ receptor-mediated inhibitory synaptic currents. AMPA receptor-mediated synaptic currents were recorded in the presence of the noncompetitive NMDA receptor antagonist 7-chlorokynurenic acid (50 $\mu \mathrm{M})$. NMDA receptor-mediated synaptic currents were recorded in the presence of the competitive AMPA receptor antagonist 6-cyano-7nitroquinoxaline-2,3-dione (CNQX; $10 \mu \mathrm{M})$ and glycine $(10 \mu \mathrm{M})$.

Application of drugs. All drugs were dissolved in distilled water or dimethylsulfoxide (DMSO) and applied by bath perfusion. The final concentration of DMSO was always $<1 \%$ in saline, a concentration that had no effect on GC EPSCs. The following compounds were used: bicuculline methobromide (Sigma, St. Louis, MO), D-2-amino-5phosphonovalerate (D-AP-5; Tocris Cookson), cyclothiazide (a generous gift of Eli Lilly, Indianapolis, IN), dihydrokainate (DHK; Sigma), QX314 (Alomone Laboratories), glutamic-pyruvic transaminase (GPT; Sigma), L-aspartate (Sigma), glycine (Sigma), 7-chlorokynurenic acid (Tocris Cookson), L-trans-pyrrolidine-2,4-dicarboxylate (PDC; Tocris Cookson) and CNQX (Tocris Cookson). Drugs were delivered to the bath by means of a peristaltic pump that fed initially into a premixing chamber above the microscope in which further gassing with $95 \% \mathrm{O}_{2}$ and $5 \% \mathrm{CO}_{2}$ was performed.

\section{RESULTS}

Contribution of transporters to single stimulus-evoked AMPA receptor-mediated currents

AMPA receptor-mediated EPSCs were recorded in the presence of $10 \mu \mathrm{M}$ bicuculline, $50 \mu \mathrm{M}$ 7-chlorokynurenate, and $1.5 \mathrm{~mm}$ external magnesium to pharmacologically isolate the AMPA component of the MF-evoked EPSC. In 13 cells, the effects of the glutamate transport inhibitor PDC $(100 \mu \mathrm{M})$ were examined on the peak amplitude, $10-90 \%$ rise time, total charge, and the time constants of decay of the EPSC evoked by single MF stimuli. PDC had no significant effect on the peak amplitude, rise time, total charge, or the fast component of decay of the EPSC $\left(\tau_{\mathrm{f}}\right.$; Fig. $1 A$, Table 1). In 8 of 13 of the cells, however, an enhancement of the slow component of decay $\left(\tau_{\mathrm{s}}\right)$ was observed, an effect that was statistically significant when data from all cells were considered $(30 \pm 3$ vs $52 \pm 12 \mathrm{msec} ; p=0.04 ; n=13)$. This slow component of the decay has been attributed to the slow phase of transmitter diff usion in the cleft at this synapse (Silver et al., 1996). However, no correlation between $\tau_{\mathrm{s}}$ and the percentage change in $\tau_{\mathrm{s}}$ produced by PDC was observed (data not shown). Application of PDC did not produce a significant change in the holding current, even when intracellular cesium methanesulphonate was replaced either by potassium gluconate $(110 \mathrm{~mm})$ and $\mathrm{CsCl}(35 \mathrm{~mm} ; n=3)$ or $\mathrm{CsNO}_{3}$ (145 mM; $n=4$; data not shown) to enhance the anionic transporter currents (Otis et al., 1997). In five cells, D-aspartate $(200 \mu \mathrm{M})$ resulted in a significant attenuation of the peak amplitude of the EPSC, while having no significant effect on the other measured parameters (Fig. $1 B$, Table 1 ). The decrease in the peak amplitude may arise from cross-desensitization of AMPA receptors caused by elevated extrasynaptic glutamate levels (Sarantis et al., 1993) or by activation of presynaptic autoreceptors that reduce glutamate release (Maki et al., 1994). D-aspartate also did not produce an observable change in the holding current. D,L-aspartate $(400 \mu \mathrm{M})$ had no effect on the single stimulus-evoked AMPA receptor-mediated EPSC recorded in five cells (Table 1), but did result in an small but significant inward current (presumably mediated by activation of NMDA receptors by L-aspartate; $-4.2 \pm 0.8 \mathrm{pA} ; p<0.05 ; n=7$ ).

\section{Effects of transport inhibition when desensitization is blocked}

It has been reported that the contribution of transporters to the diffusion of glutamate from the synaptic cleft can be observed when AMPA receptor desensitization is blocked by cyclothiazide (Mennerick and Zorumski, 1994, 1995). To investigate the possibility that AMPA receptor desensitization masks the effect of transport inhibition at the MF-GC synapse, AMPA receptormediated EPSCs were recorded in the presence of cyclothiazide. Cyclothiazide $(100 \mu \mathrm{M})$ alone produced a greater than twofold increase in the normalized peak amplitude, total charge, and the time constants of decay of the EPSC ( $\tau_{\text {fast }}$ and $\tau_{\text {slow }}$; Fig. $\left.1 C-G\right)$. The subsequent application of PDC $(100 \mu \mathrm{M})$ in the presence of cyclothiazide resulted in a further increase in the total charge $(40 \pm 11 \% ; p<0.05 ; n=8)$ and $\tau_{\text {slow }}(177 \pm 61 \% ; p<0.05 ; n=$ 8 ; Fig. $1 C, E, G)$. These results suggest that AMPA receptor desensitization can mask the effects of inhibition of glutamate transport. In addition to blocking AMPA receptor desensitization, cyclothiazide has been reported to alter AMPA receptormediated currents by enhancing release (Diamond and Jahr, 
A i

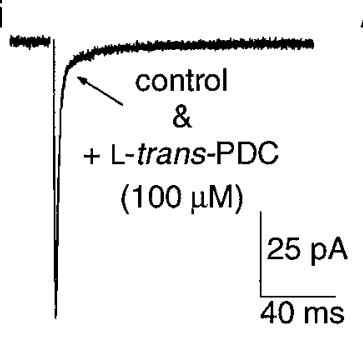

A ii

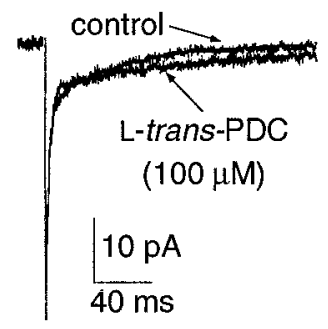

B

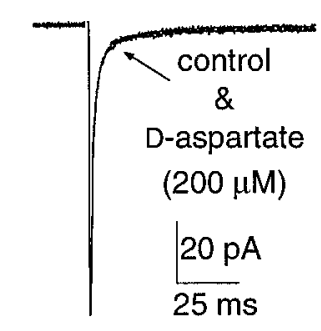

D

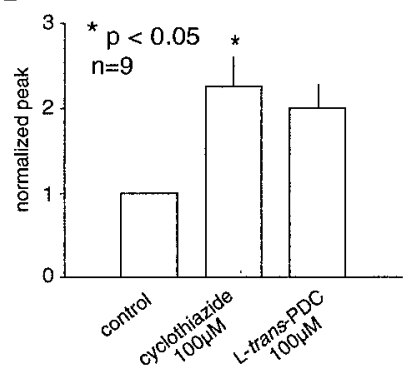

E

$\mathrm{F}$

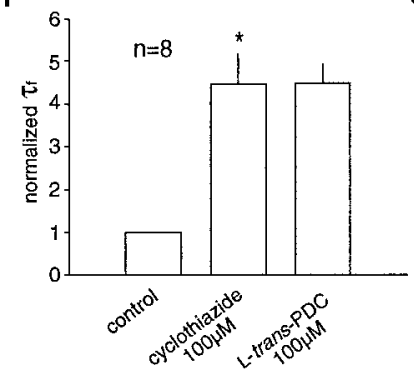

G

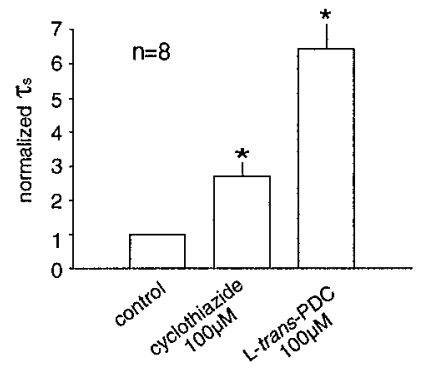

Figure 1. AMPA receptor desensitization masks a prolongation of the EPSC during transport inhibition. $A$, Impairment of glutamate transport by PDC $(100 \mu \mathrm{M})$ produced no effects on the AMPA-receptor mediated EPSC recorded in some granule cells $(A i)$ while causing a modest prolongation of the slow component of decay in other cells (Aii). B, D-Aspartate $(200 \mu \mathrm{M})$ did not significantly prolong any component of the decay of a single MF-evoked EPSC. $C$, When AMPA receptor desensitization was blocked by cyclothiazide $(100 \mu \mathrm{M})$, PDC prolonged the decay of the synaptic current. Histograms illustrating the effect of cyclothiazide and PDC on the peak amplitude $(D)$, total area $(E)$, decay $\tau_{\text {fast }}(F)$, and decay $\tau_{\text {slow }}(G)$. Data are normalized to control values. All values presented in this and the following figures are the mean \pm SEM for the number of experiments indicated in the histograms. Asterisks indicate significant difference between groups using a paired $t$ test at the $p<0.05$ level.

1995). Because the contribution of transporters to glutamate clearance may be accentuated during conditions of high release probability (Mennerick and Zorumski, 1995), further experiments were required to determine what specific effects could be attributed to the transporters in the presence of cyclothiazide.

\section{PDC prolongs repetitive stimulus-evoked AMPA receptor-mediated currents}

If the contribution of transporters to glutamate clearance is more conspicuous under conditions of high release probability, it was anticipated that transporter inhibition would have a pronounced effect on the synaptic current after repetitive stimuli. This is of functional relevance at the MF-granule cell synapse because granule cells in the cerebellar nodulus receive MF afferents from sources such as brainstem vestibular nuclei and primary vestibular afferents (Korte and Mugnaini, 1979; Gerrits et al., 1989; Barmack et al., 1992), that fire at high frequencies during head rotation in vivo (>200 Hz; Goldberg and Fernandez, 1971). In contrast to the modest effects of PDC on single AMPA receptormediated EPSCs (Fig. 1A), PDC $(100 \mu \mathrm{M})$ significantly prolonged the synaptic current after a short burst of MF stimuli at $50 \mathrm{~Hz}$ ( $n=13$; Fig. $2 A, C$ ). The decay of the AMPA receptor-mediated synaptic current was quantified by three parameters: the total charge (area), the postburst decay $\tau$ fit by a single exponential, and the absolute amplitude measured $20 \mathrm{msec}$ after the final MF stimulus. PDC slowed the decay of the synaptic current $(\tau=$ $121 \pm 11$ vs $228 \pm 23 \mathrm{msec} ; p<0.05)$ and increased the total charge $(1349 \pm 180$ vs $2547 \pm 339 \mathrm{fC} ; p<0.05)$ without a significant change in the amplitude $(6.5 \pm 0.5$ vs $7.2 \pm 0.8 \mathrm{pA}$; Fig. $2 C)$. Similar results were also obtained in five cells using D-aspartate $(200 \mu \mathrm{M})$ on the decay $(\tau=194 \pm 63$ vs $378 \pm 84$ msec; $p<0.05)$, total area $(560 \pm 342$ vs $1689 \pm 437 \mathrm{fC} ; p<0.05)$, and amplitude $(3.0 \pm 0.6$ vs $4.4 \pm 0.8$ pA; Fig. $2 D)$. Application of D,L-aspartate also resulted in a significant slowing of the current decay $(\tau=188 \pm 43$ vs $417 \pm 72 \mathrm{msec} ; p<0.05)$ and increase in the total charge $(1060 \pm 246$ vs $2256 \pm 452 \mathrm{fC} ; p<$ $0.05)$ after repetitive stimuli ( $n=7$; data not shown). These results indicate that transporters contribute to the time course of excitatory transmission at the MF-GC synapse during physiologically relevant stimulus protocols.

\section{PDC prolongs the EPSC by blocking transporter binding sites}

In addition to buffering the synaptic glutamate transient (Tong and Jahr, 1994, Diamond and Jahr, 1997; Otis et al., 1997), transporters maintain low levels of ambient extracellular glutamate (Rothstein et al., 1996; Takahashi et al., 1997; Tanaka et al., 1997). Indeed, application of PDC in the absence of $\mathrm{Mg}^{2+}$ produced an increase in the holding current, presumably caused by NMDA receptor activation after an increase in extracellular glutamate (data not shown). Accumulation of glutamate may be exacerbated by glutamate heteroexchange as PDC is transported into cells (Barbour et al., 1991; Arriza et al., 1994). To determine whether the accumulation of glutamate or the blockade of transporter binding sites was responsible for the prolongation of the EPSC, repetitive stimuli were delivered in the presence of PDC before and after the enzymatic degradation of resting glutamate levels with GPT. GPT $(10 \mathrm{U} / \mathrm{ml})$ selectively metabolizes endogenous extracellular glutamate to $\alpha$-ketoglutarate in the presence of elevated concentrations of pyruvic acid (2 mM; O'Brien and Fischbach, 1986; Rossi and Slater, 1993; Min et al., 1998). If the prolongation of the EPSC decay was related to the accumulation of extracellular glutamate produced by PDC rather than blockade of transporter binding sites, then GPT would be expected to attenuate the prolongation. In six cells, PDC produced a significant increase in the AMPA receptor-mediated synaptic current decay $\tau(142 \pm 19$ vs $239 \pm 25 \mathrm{msec} ; p<0.05)$ and total area 


\begin{tabular}{|c|c|c|c|c|c|c|}
\hline & $\begin{array}{l}\text { Peak amp } \\
\text { (pA) }\end{array}$ & $\begin{array}{l}\text { Total charge } \\
(\mathrm{pA} \cdot \mathrm{msec})\end{array}$ & $\begin{array}{l}10-90 \% \text { rise } \\
(\mathrm{msec})\end{array}$ & $\begin{array}{l}\text { Decay } \tau_{\text {fast }} \\
(\mathrm{msec})\end{array}$ & $\begin{array}{l}\text { Decay } \tau_{\text {slow }} \\
(\mathrm{msec})\end{array}$ & $\begin{array}{l}\text { Decay } \tau_{\text {fast }} \\
\text { amp }(\%)\end{array}$ \\
\hline Control (13) & $-70 \pm 8$ & $-644 \pm 93$ & $0.57 \pm 0.02$ & $2.0 \pm 0.2$ & $30 \pm 3$ & $82 \pm 2$ \\
\hline PDC (13) & $-66 \pm 8$ & $-694 \pm 118$ & $0.60 \pm 0.04$ & $2.3 \pm 0.3$ & $52 \pm 12^{*}$ & $85 \pm 2$ \\
\hline Control (5) & $-64 \pm 19$ & $-350 \pm 88$ & $0.62 \pm 0.01$ & $2.2 \pm 0.1$ & $30 \pm 8$ & $89 \pm 3$ \\
\hline D-asp (5) & $-58 \pm 17^{*}$ & $-436 \pm 60$ & $0.64 \pm 0.16$ & $2.3 \pm 0.4$ & $31 \pm 8$ & $86 \pm 3$ \\
\hline Control (5) & $-52 \pm 18$ & $-392 \pm 68$ & $0.58 \pm 0.09$ & $2.1 \pm 0.2$ & $30 \pm 5$ & $83 \pm 4$ \\
\hline D,L-asp (5) & $-45 \pm 19$ & $-357 \pm 33$ & $0.62 \pm 0.10$ & $2.4 \pm 0.1$ & $27 \pm 6$ & $84 \pm 4$ \\
\hline
\end{tabular}

Mean \pm SEM.

${ }^{*} p<0.05$, paired $t$ test.

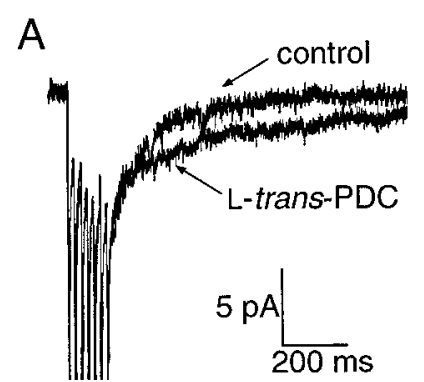

B
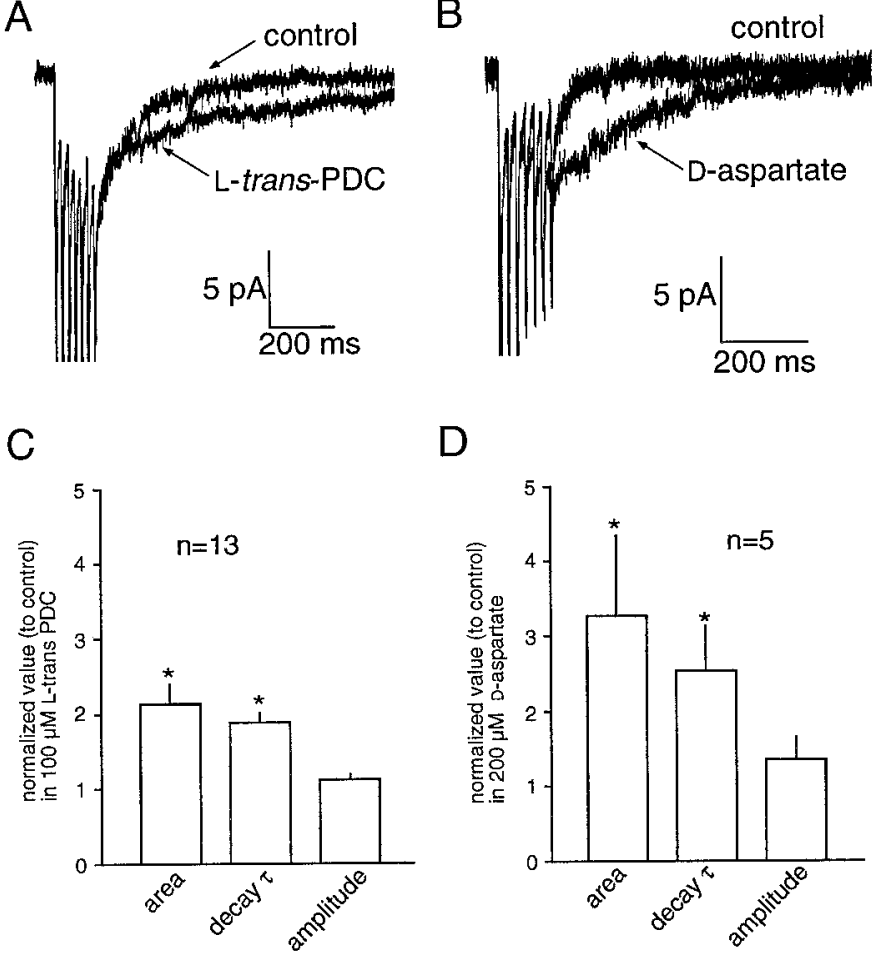

Figure 2. Transport impairment slows the decay of AMPA receptormediated EPSCs after repetitive MF stimulation. $A$, PDC prolongs the decay of AMPA receptor-mediated EPSCs evoked by repetitive stimuli (7 stimuli at $50 \mathrm{~Hz}) . B$, Inhibition of uptake by D-aspartate $(200 \mu \mathrm{M})$ mimicked the effects of PDC on the EPSC decay after repetitive stimuli. Histograms summarizing the effect of PDC $(C)$ and D-aspartate $(D)$ on the time course of EPSCs. In all recorded cells, inhibition of uptake increased the total area and slowed the time constant of decay after repetitive stimulation. There was no change in the amplitude of the current measured $20 \mathrm{msec}$ after the final stimulus. The peaks of the EPSCs have been truncated.

$(1394 \pm 362$ vs $3055 \pm 559 \mathrm{fC} ; p<0.05)$ after the repetitive stimulus (Fig. $3 A$ ). The subsequent addition of GPT $(10 \mathrm{U} / \mathrm{ml})$, a concentration sufficient to return the extrasynaptic glutamate concentration to control levels after the inhibition of glutamate transport (Rossi and Slater, 1993), did not result in a significant change in the decay $\tau$ or total area (Fig. $3 B-D$ ). Thus, elevation of resting glutamate levels by $\mathrm{PDC}$ is not responsible for the prolongation of the synaptic current. Rather, this data suggests that interference with the binding of glutamate to transporter sites underlies the action of PDC.

\section{Effect of transport impairment on NMDA receptor-mediated EPSCs}

Although the time course of NMDA receptor-mediated currents primarily reflects receptor properties rather than the time course of glutamate within the cleft (Lester et al., 1990; Edmonds and Colquhoun, 1992; Clements 1996; Ebralidze et al., 1996; Takahashi et al., 1996b), NMDA receptors have a much higher glutamate binding affinity (Olverman et al., 1984) than AMPA receptors (Patneau and Mayer, 1990). Therefore, the time course of the NMDA receptor-mediated EPSC may be more sensitive to spillover after transport impairment. NMDA receptor-mediated EPSCs were pharmacologically isolated and recorded in the presence of $10 \mu \mathrm{M}$ glycine. Under control conditions, the decay of the NMDA receptor-mediated EPSC was best fit by two exponentials $\left(\tau_{\text {fast }}=32.7 \pm 4.7 \mathrm{msec} ; \tau_{\text {slow }}=244 \pm 58 \mathrm{msec} ; n=9\right)$. However, in the majority of cells, the decay of the EPSC recorded in the presence of PDC could no longer be adequately fit by two exponentials. The NMDA receptor-mediated current was prolonged in the presence of $100 \mu \mathrm{M}$ PDC, as evidenced by the significant increase in the $\mathrm{t}_{1 / 2}$ of decay after single stimuli $(46.9 \pm 7.4 \mathrm{vs}$ $94.7 \pm 15.9 \mathrm{msec} ; p<0.05 ; n=9)$ and repetitive stimuli (103 \pm 6.5 vs $398 \pm 108$ msec; $p<0.05 ; n=9)$. PDC also resulted in an increase in the total charge (measured in a $1.5 \mathrm{sec}$ bin after the onset of the EPSC) after both single $(2228 \pm 257$ vs $4110 \pm 348$ fC; $p<0.05 ; n=9$; Fig. 4$)$ and repetitive (6941 \pm 1043 vs $40815 \pm$ $11678 \mathrm{fC} ; p<0.05 ; n=9$; Fig. 5) stimuli. PDC produced an increase in the resting current noise, presumably because of tonic activation of NMDA receptors by the raised extracellular glutamate concentration. However, the concentration of PDC used $(100 \mu \mathrm{M})$ was low enough to avoid significant desensitization of NMDA receptors, as has been observed previously (Sarantis et al., 1993). In six of nine cells, the application of PDC reduced the peak NMDA current (Fig. 5B), but this effect was not statistically significant when data from all the cells were combined (20.9 \pm 2.07 vs $18.1 \pm 1.01 \mathrm{pA})$.

Dihydrokainate (DHK) is an uptake blocker that is relatively selective for the GLT-1 (EAAT2) subtype of glial glutamate transporter (Arriza et al., 1994). GLT-1, GLAST (EAAT1), and the neuronal transporter EAAC1 (EAAT3) are expressed in the granule cell layer of the cerebellum (Rothstein et al., 1994; Lehre et al., 1995; Furuta et al., 1997). To investigate the subtype of transporter underlying the prolongation of EPSCs by PDC, the effect of DHK was measured on NMDA receptor-mediated EPSCs evoked by single and repetitive stimuli. A concentration of DHK $(300 \mu \mathrm{M})$ that produced approximately as much inhibition as $100 \mu \mathrm{M}$ PDC at GLT-1 (EAAT2; Arriza et al., 1994) was used. In five cells, DHK had no effect on the $t_{1 / 2}$ of decay of the NMDA receptor-mediated EPSC evoked by single ( $95 \pm 18$ vs $84 \pm 12$ 

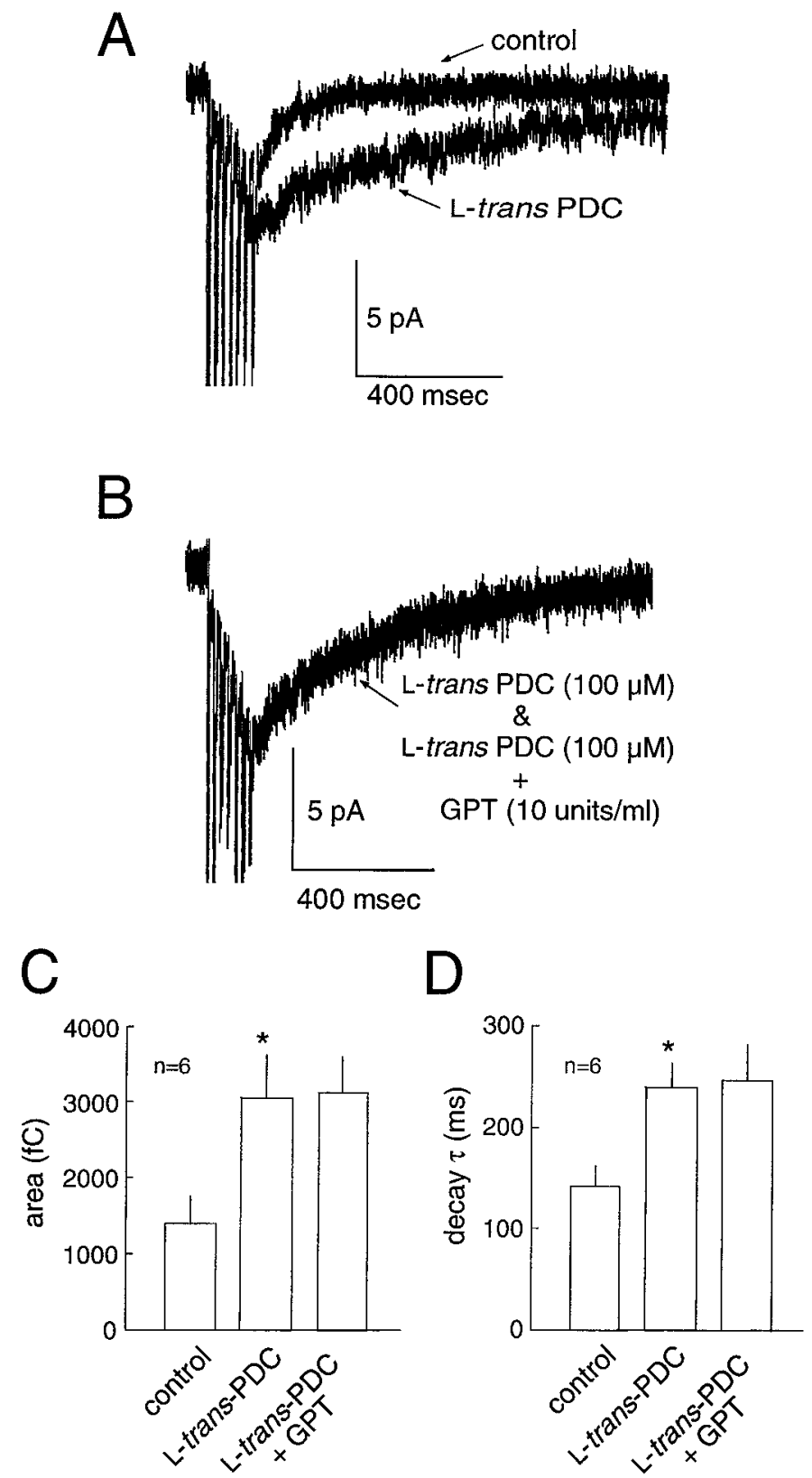

Figure 3. Transporter binding sites, not the ambient glutamate level, modulates the decay of the EPSC. $A$, An example of the slowing of synaptic current decay by PDC after repetitive stimulation. $B$, In the presence of PDC (data from same cell as in $A$ ), metabolic degradation of the extracellular glutamate by GPT (in the presence of $2 \mathrm{~mm}$ pyruvate) does not restore the time course of the current decay to control levels. GPT produced no change in the area $(C)$ or decay $\tau(D)$ of the EPSC. Thus, elevation of resting glutamate levels by PDC is not responsible for the prolongation of the synaptic current.

msec) or repetitive $(120 \pm 21$ vs $124 \pm 25 \mathrm{msec})$ stimuli (Fig. 6). DHK also failed to produce an increase in the holding current, suggesting the extracellular glutamate concentration was not significantly increased. In three of three cells in which DHK had no effect on the $t_{1 / 2}$ or holding current, the subsequent application of $100 \mu \mathrm{M}$ PDC prolonged the EPSC and produced an increase in the holding current as described above (data not shown). DHK produced a significant reversible attenuation of the peak NMDA receptor-meditated EPSC $(-30 \pm 5.4$ vs $-16 \pm 3.2 \mathrm{pA} ; p<0.05$;
A

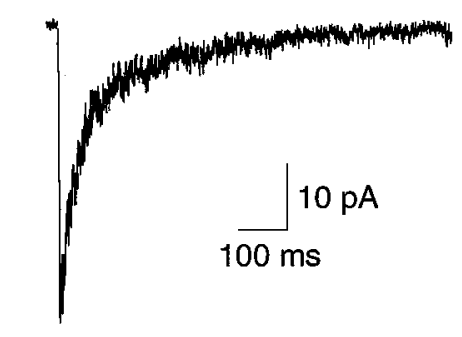

B
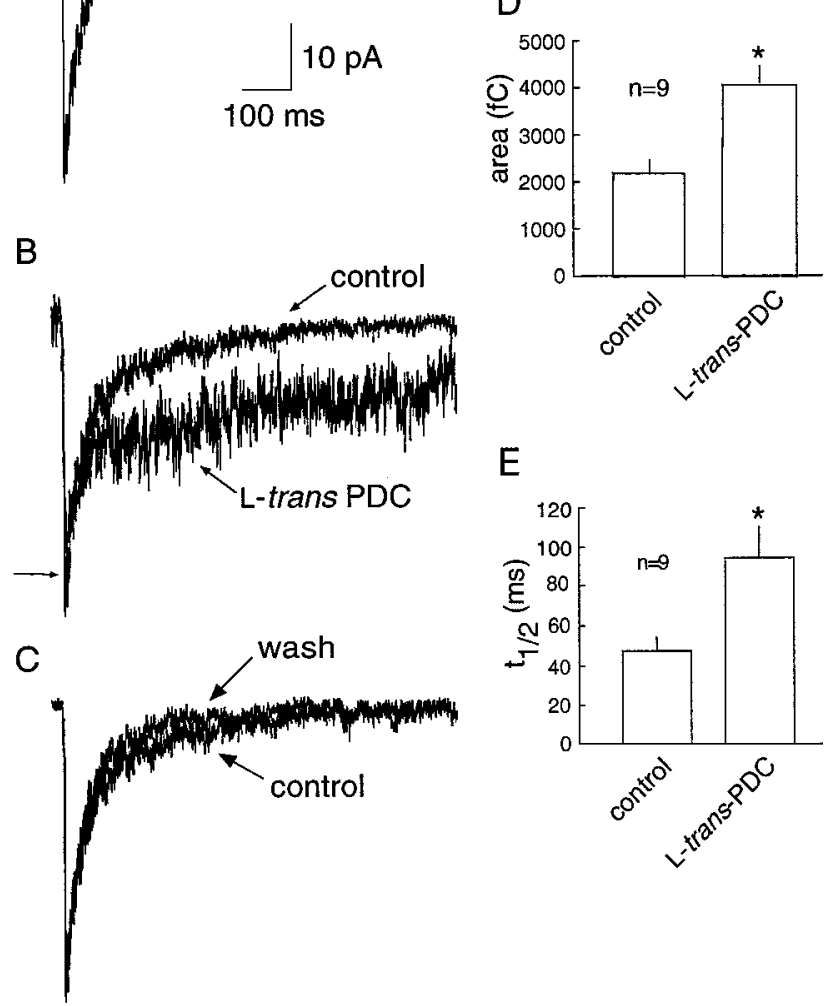

$\mathrm{E}$

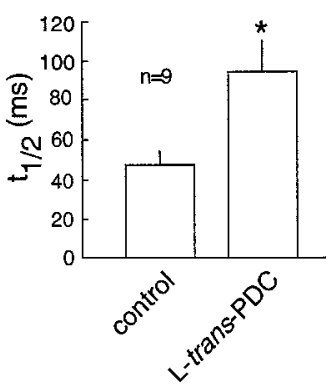

Figure 4. NMDA receptor-mediated EPSCs evoked by single stimuli are prolonged in the presence of PDC. A, An example of a NMDA receptormediated EPSC evoked by a single stimulus. The decay of the EPSC was fitted with the sum of two exponentials $\left(\tau_{\text {fast }}=32.7 \pm 4.7 \mathrm{msec} ; \tau_{\text {slow }}=\right.$ $244 \pm 58.7 \mathrm{msec} ; n=9$; data not shown). $B$, In the presence of $100 \mu \mathrm{M}$ PDC, the decay is prolonged, and no longer fit by two exponentials. The peak amplitude in PDC is indicated by the small arrow. The baseline in PDC is aligned with control to emphasize the change in the time course of the decay. $C$, The EPSC recorded after washout of PDC, compared with control (from $A$ ). $D$, PDC produced an increase in the total charge, measured during the $1500 \mathrm{msec}$ time frame illustrated in $A-C$. E, PDC also produced an increase in the half decay time.

$n=5$; Fig. $6 A$ ), that resulted in a significant reduction in the total charge after both single $(5103 \pm 842$ vs $2140 \pm 394 \mathrm{fC})$ and repetitive (11784 \pm 2445 vs $7279 \pm 1455 \mathrm{fC} ; p<0.05)$ stimuli. This reduction may be caused by a direct action of DHK on NMDA receptors (Wang et al., 1998).

\section{Effect of transport impairment on EPSPs}

To investigate the role of glutamate transporters in regulating synaptic transmission under more physiological conditions, the effect of transport inhibition on EPSPs was examined in the presence of $1.5 \mathrm{~mm}$ external magnesium. In current-clamp recordings of MF-evoked EPSPs in granule cells, $100 \mu \mathrm{M}$ PDC increased the total area of the EPSP evoked by single stimuli $(2619 \pm 578$ vs $12763 \pm 3885 \mathrm{mV} \cdot \mathrm{msec} ; p<0.05 ; n=7)$ and repetitive stimuli (7780 \pm 3140 vs $33287 \pm 14934 \mathrm{mV} \cdot \mathrm{msec} ; n=5$; Fig. 7). In addition, PDC produced an increase in the number of spikes induced per MF stimuli (Fig. 7). These results indicate that the prolongation of synaptic currents produced by inhibition of trans- 

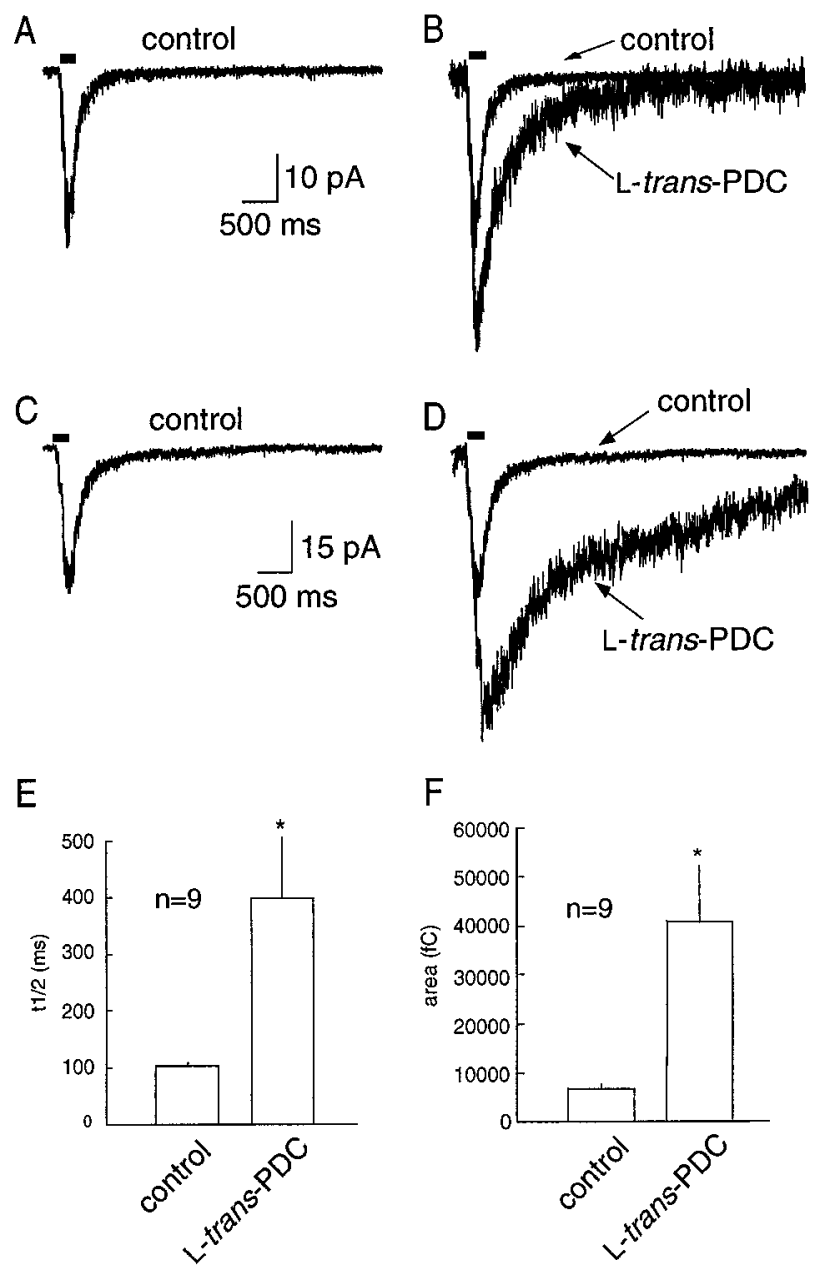

Figure 5. NMDA receptor-mediated EPSCs evoked by repetitive stimuli are prolonged in the presence of PDC. $A$, An example of an NMDA receptor-mediated EPSC evoked by repetitive stimuli (solid bar; 7 stimuli at $50 \mathrm{~Hz}$ ). $B$, A $100 \mu \mathrm{M}$ concentration of PDC results in a prolongation of the EPSC decay. $C, D$, Another example illustrating the marked prolongation in the synaptic current produced by transport impairment by PDC. $E$, PDC produced an increase in the half width of the decay $(n=9) . F$, PDC produced an increase in the total charge, measured during the $4 \mathrm{sec}$ time frame illustrated in $A-D$.

port is of physiological significance, because robust effects of PDC can be seen with current-clamp recordings in the presence of external magnesium.

Granule cells in the cerebellar nodulus receive afferent input from MFs that originate from both primary vestibular afferents and second-order vestibular neurons in the brainstem, and these afferents fire over a frequency range of $50-300 \mathrm{~Hz}$ in vivo (Goldberg and Fernandez, 1971). To assess how glutamate transporters sculpt the activity of granule cells in response to afferent stimuli that approximate those encountered in vivo, the response to synaptic stimuli over the frequency range $50-333 \mathrm{~Hz}(50 \mathrm{msec}$ duration) was studied with current-clamp recording in the presence of $1.5 \mathrm{~mm}$ external magnesium. In control, the delivery of MF stimuli evoked a temporally summating EPSP and associated burst of action potentials (Fig. $8 A-C$ ). Single stimuli evoked an EPSP with either no action potential (Fig. $8 A$ ) or one or two action potentials (Fig. $7 A$ ). With increasing stimulus frequency, the duration of the burst of action potentials progressively increased (Fig. 8D). In the majority of cells studied (four of six), the
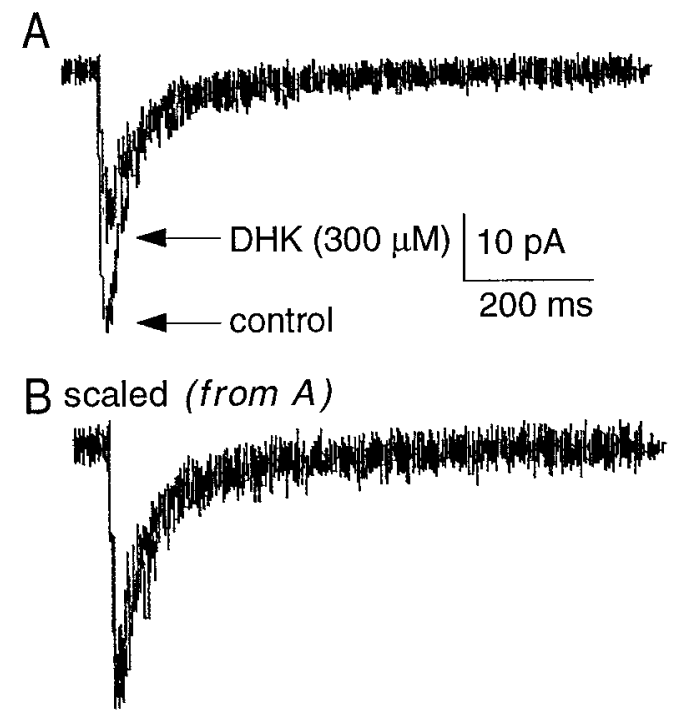

Figure 6. Lack of effect of DHK on the time course of NMDA receptormediated EPSCs. $A$, NMDA receptor-mediated EPSCs recorded before and after the bath application of DHK $(300 \mu \mathrm{M})$. B, The EPSC in the presence of DHK scaled to the peak of the control response, illustrating the lack of effect of DHK on the time course of the EPSC.

amplitude of the depolarization during the EPSP in the presence of PDC $(30 \mu \mathrm{M})$ was sufficient to produce a rapid inactivation of spiking (Fig. $8 B, C$ ). In three of these four cells, the normalized EPSP area was potentiated at all frequencies (Fig. $8 E$ ), primarily reflecting an increased EPSP duration. In two cells in which spike inactivation did not occur in the presence of PDC, an increase in burst duration was also observed at all frequencies (Fig. 9A-C). Analysis of the instantaneous firing frequency during the burst revealed that a maximal postburst firing frequency was established ( $\sim 60 \mathrm{~Hz}$ in the cell illustrated in Fig. 9D,E), both in control and in the presence of PDC; application of PDC prolonged the burst (Fig. 9E), but the instantaneous firing rate over most of the range of frequencies examined remained similar. These results suggest that, under control conditions, the glomerular synapse acts essentially as a frequency-to-duration converter, encoding changes of input frequencies into outputs of varying duration. When glutamate transporters are impaired in the presence of PDC, the underlying EPSP is prolonged in duration and thus, total area (Fig. $8 E$ ), and the associated burst of spikes is also prolonged at all frequencies (Fig. 9B,C). Therefore, glutamate transporters regulate the temporal dynamics of signal processing across the range of afferent firing frequencies normally encountered in vivo in this region of cerebellum.

\section{DISCUSSION}

\section{Transport contributes to synaptic transmission at the MF-GC synapse}

The results of this study demonstrate that glutamate transport contributes to the time course of synaptic transmission at the mossy fiber-granule cell synapse. This is most clearly illustrated by the finding that $100 \mu \mathrm{M}$ PDC produces a significant increase in the total area of the EPSP evoked by a single MF stimulus (Fig. 7). The prolongation of the depolarization was mediated primarily by an enhancement of the NMDA receptor-mediated component (Fig. 4), because prolongation of the AMPA component was masked by desensitization (Fig. 1). The contribution of transporters to transmission was particularly striking during repetitive 

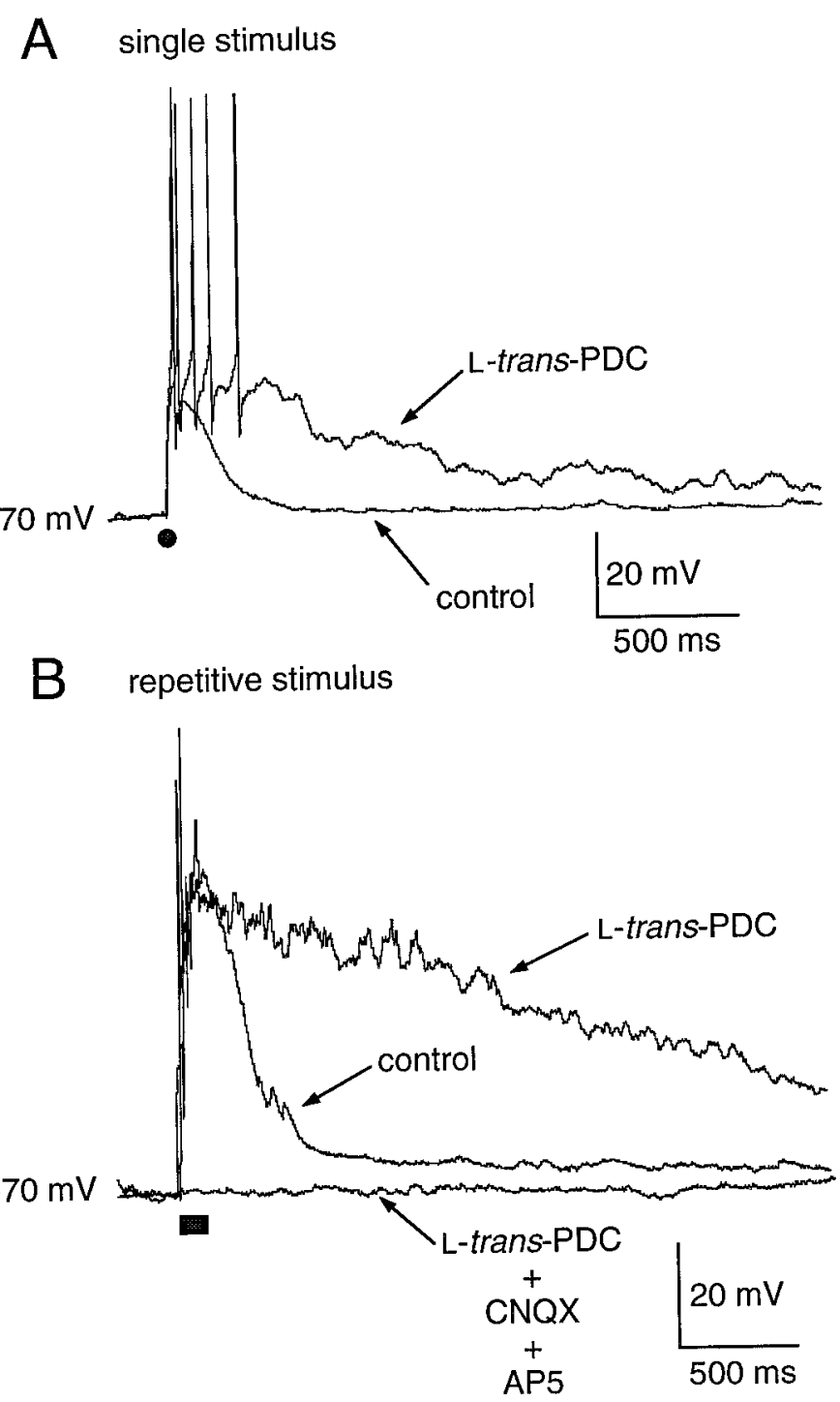

Figure 7. Impairment of glutamate transport prolongs single and repetitive stimulus-evoked EPSPs. $A$, Application of PDC results in a prolongation of a single stimulus-evoked EPSP (solid circle). B, PDC also produces a significant prolongation of the EPSP evoked by a repetitive stimulus (solid bar; 7 stimuli at $50 \mathrm{~Hz}$ ).

stimulus protocols at physiologically relevant frequencies, as illustrated by the substantial prolongation of both the AMPA and NMDA receptor-mediated EPSC, and the EPSP after a repetitive stimulus (Figs. 2, 5, 7, 8).

The prolongation of the EPSC and EPSP produced by PDC is most likely caused by enhanced spillover onto adjacent granule cell dendritic membranes within the glomerulus, because relatively small changes in the cleft glutamate transient produced by uptake inhibition (Diamond and Jahr, 1997) are unlikely to produce the large changes in the EPSC and EPSP observed in this study (Figs. 4,7). The greater prolongation of the NMDA receptor-mediated component compared with the AMPA receptor-mediated component is consistent with the higher affinity of glutamate for NMDA receptors. This is consistent with the proposal that the discrepancy in quantal content mediated by the two receptors is caused by the greater sensitivity of NMDA receptors to spillover (Asztely et al., 1997). The prolonged depolarization recorded in PDC is mediated by AMPA and NMDA receptors, because it is completely blocked in the presence of AP-5 and CNQX (Fig. 7B). It is also unlikely to be the result of a direct action on postsynaptic receptors; $100 \mu \mathrm{M}$ PDC has been shown to cause a slight reduction of NMDA receptor-mediated currents while having no effect on currents evoked by AMPA (Sarantis et al., 1993). The reduction in NMDA-evoked currents produced by PDC is consistent with a reduction in glutamate binding to NMDA receptors (Bridges et al., 1991; Sarantis et al., 1993; Matsui et al., 1999) or desensitization by elevated glutamate (Sarantis et al., 1993), either of which may result in an underestimation of the enhancement of spillover produced by PDC.

It has been demonstrated previously that repetitive stimulation of cerebellar MFs produces a temporally summating EPSP whose voltage envelope is largely accounted for by the recruitment of NMDA receptors (D'Angelo et al., 1995). This is doubtless also the case for control responses in the present study (Figs. $7 B$, $8 B, C)$, and for the enhanced EPSP observed in the presence of PDC. This would be expected both because glutamate has a higher affinity for NMDA receptors and because the enhancement of total charge produced by PDC was greater for NMDA receptor-mediated EPSCs than for AMPA receptor-mediated synaptic responses (Fig. $2 A$ vs Fig. $5 B, D$ ).

The results presented here are consistent with the central hypothesis of Sarantis et al. (1993) that glutamate uptake does not shape the decay of the AMPA receptor-mediated component of the synaptic current evoked by a single stimulus. Although PDC did produce an increase in the decay $\tau_{\text {slow }}$ of the AMPA receptor-mediated EPSC evoked by a single stimulus in some of the recorded granule cells, the effect was not robust and was not observed during transporter impairment with D- and D,Laspartate (Table 1). However, when AMPA receptor desensitization was blocked by cyclothiazide, PDC produced a more significant slowing of the decay $\tau_{\text {slow }}$ (Fig. 1). This may reflect an enhanced sensitivity to low concentrations of glutamate and thus an increase in AMPA receptor-mediated current produced by glutamate released from neighboring terminals.

One possible caveat to the physiological significance of this study is that stimuli were delivered by a bipolar electrode placed in the white matter, therefore activating a large number of MF afferents that may produce significantly more spillover between glomeruli than occurs under native conditions. Such situations have been reported to promote the importance of glutamate transport (Barbour and Häusser, 1997). However, increasing the stimulus intensity did not influence the magnitude of the prolongation of AMPA receptor-mediated EPSCs evoked by a repetitive stimulus ( $n=5$; data not shown), suggesting that nonphysiological interglomerular spillover caused by synchronous MF activation did not overestimate the contribution of transporters.

\section{Transporter binding sites are crucial}

One complete cycle of glutamate transport across the cell membrane takes $\sim 70 \mathrm{msec}$ (Wadiche et al., 1995b). Hence, it has been suggested that glutamate binding, rather than translocation, may contribute to the time course of the glutamate transient within the synaptic cleft (Tong and Jahr, 1994; Diamond and Jahr, 1997). In addition to competing with glutamate for transporter binding sites, transport inhibitors also can elevate the ambient extracellular glutamate level. In our preparation, $100 \mu \mathrm{M}$ PDC produced an increase in holding current only in the absence of $\mathrm{Mg}^{2+}$, suggesting that the rise in ambient glutamate was sufficient to activate NMDA receptors, but not AMPA receptors. Because $\mathrm{PDC}$ is a transport substrate, glutamate heteroexchange may have 


\section{A Single Stimulus}

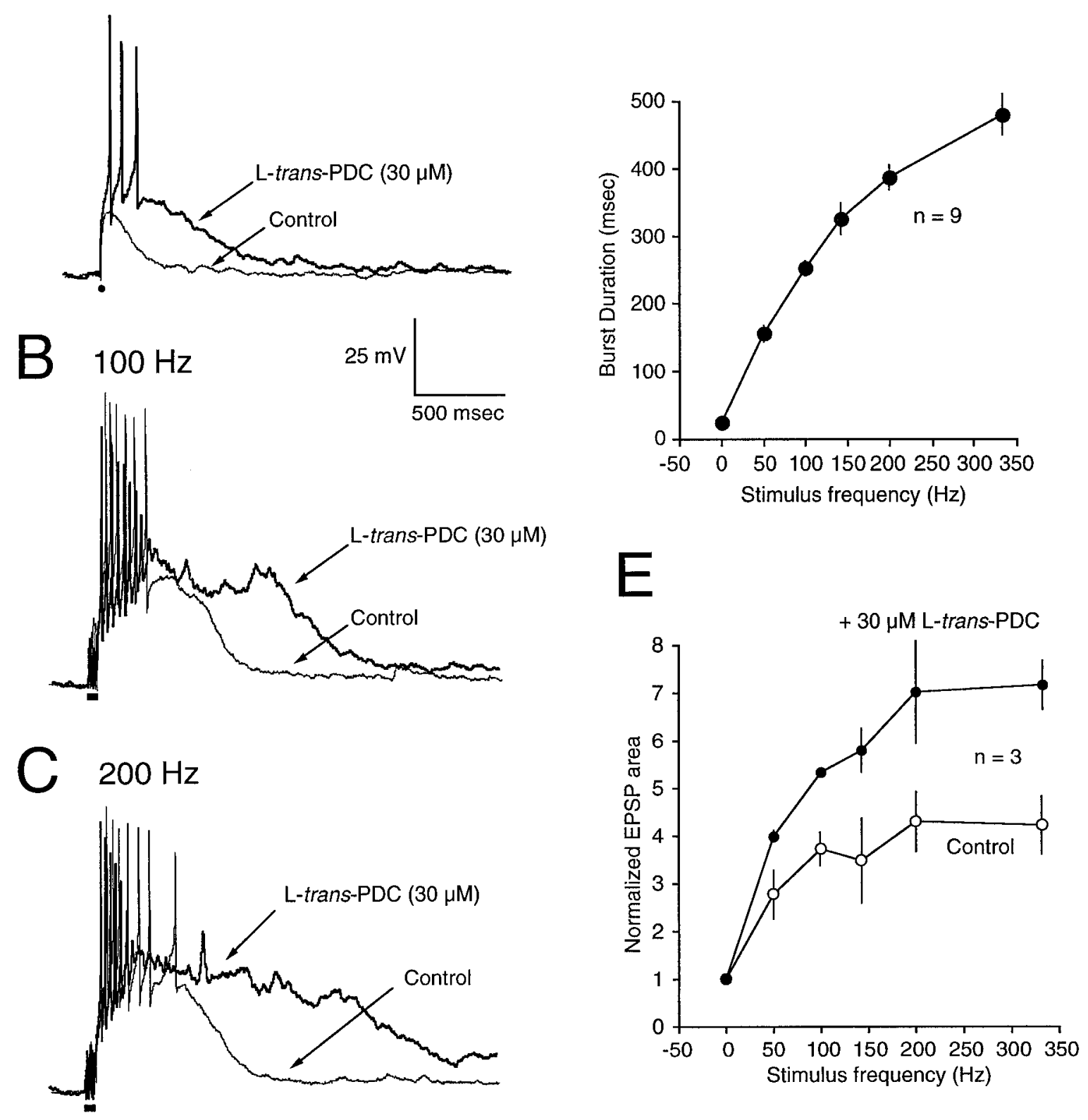

Figure 8. Effects of PDC on responses to repetitive synaptic stimulation. $A-C$, EPSPs recorded in granule cells in response to a single MF stimulus $(A$, solid circle) or repetitive stimuli (solid bar) at $100 \mathrm{~Hz}(B)$ or $200 \mathrm{~Hz}(C)$. In each pair of recordings, the response in the presence of PDC (30 $\mu \mathrm{M})$ is shown by the bold line. $D$, Relation between the duration of the burst of action potentials evoked by stimuli of varying frequencies (50 msec duration). Each point represents the mean \pm SE for data from nine granule cells. $E$, Relation between stimulus frequency and the normalized area of the EPSP recorded before (Control) and after the application of PDC $(30 \mu \mathrm{M})$. Each point represents the mean \pm SE for data from three granule cells. The EPSP area and burst duration at each stimulus frequency have been normalized to the EPSP area and burst duration produced by a single stimulus. This is drawn as the point at a frequency $=0$ for illustrative purposes

contributed to the accumulation of extracellular glutamate (Barbour et al., 1991; Arriza et al., 1994). To differentiate between the glutamate accumulation and block of transporter binding sites produced by PDC, enzymatic degradation of extracellular glutamate by GPT was used to reduce the extracellular glutamate concentration while transporters remained occupied by PDC. The prolongation of the AMPA receptor-mediated EPSC observed in the presence of PDC was not reduced when GPT was added to the bath (Fig. $3 B$ ), suggesting that the change in extrasynaptic glutamate concentration produced by transporter impairment did not underlie the prolongation of the current. Hence, it is likely that available transporter binding sites, which are occupied by PDC, are crucial to limiting spillover.

\section{Glial transporters contribute to synaptic transmission}

Transmembrane currents elicited by activation of glutamate transporters have been described in a number of preparations (Szatkowski et al., 1990; Barbour et al., 1991; Fairman et al., 1995; Wadiche et al., 1995a,b; Eliasof and Jahr, 1996; Mennerick et al., 1996; Takahashi et al., 1996a; Castagna et al., 1997; Clark and 

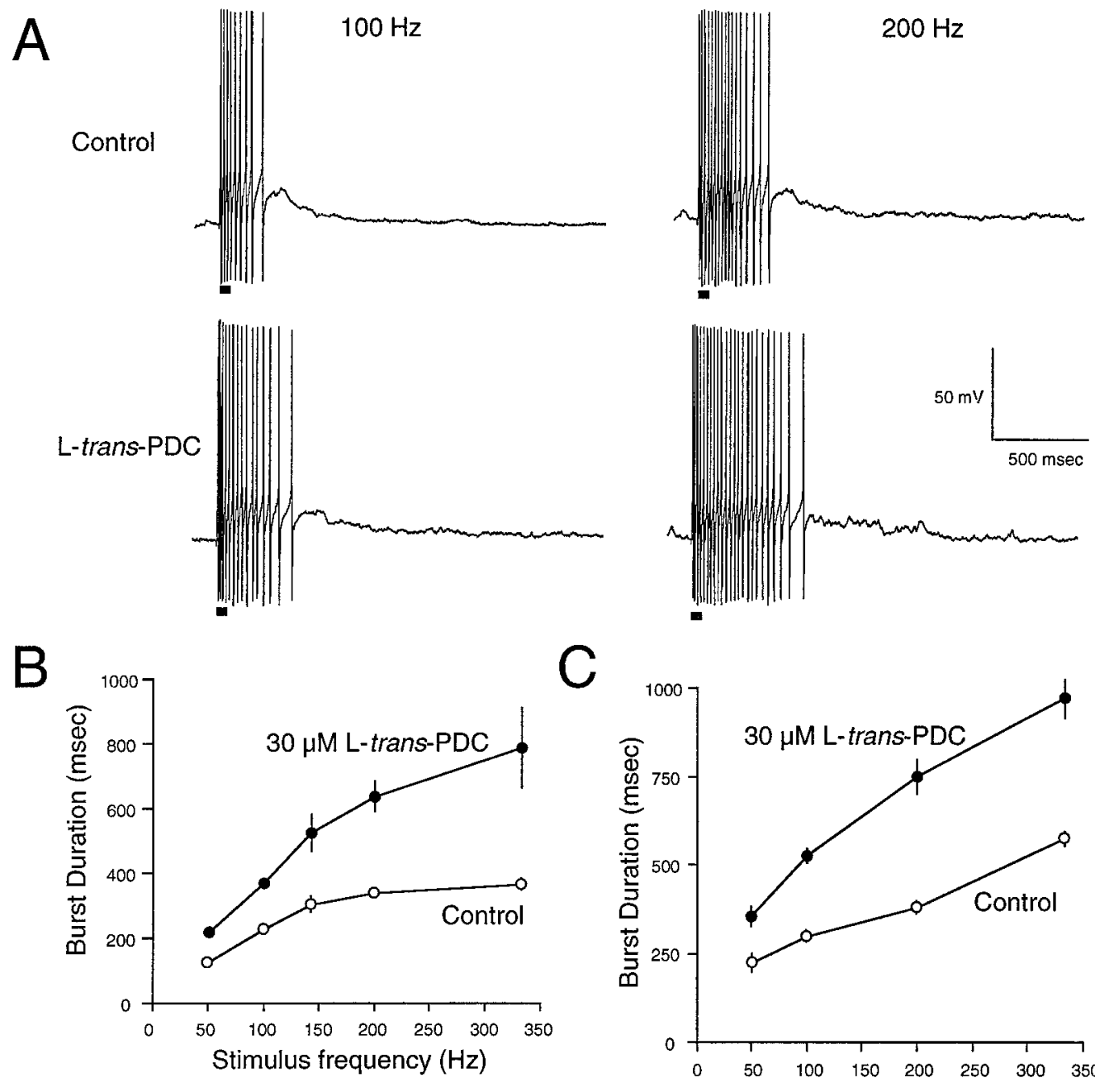

$\mathrm{D}$
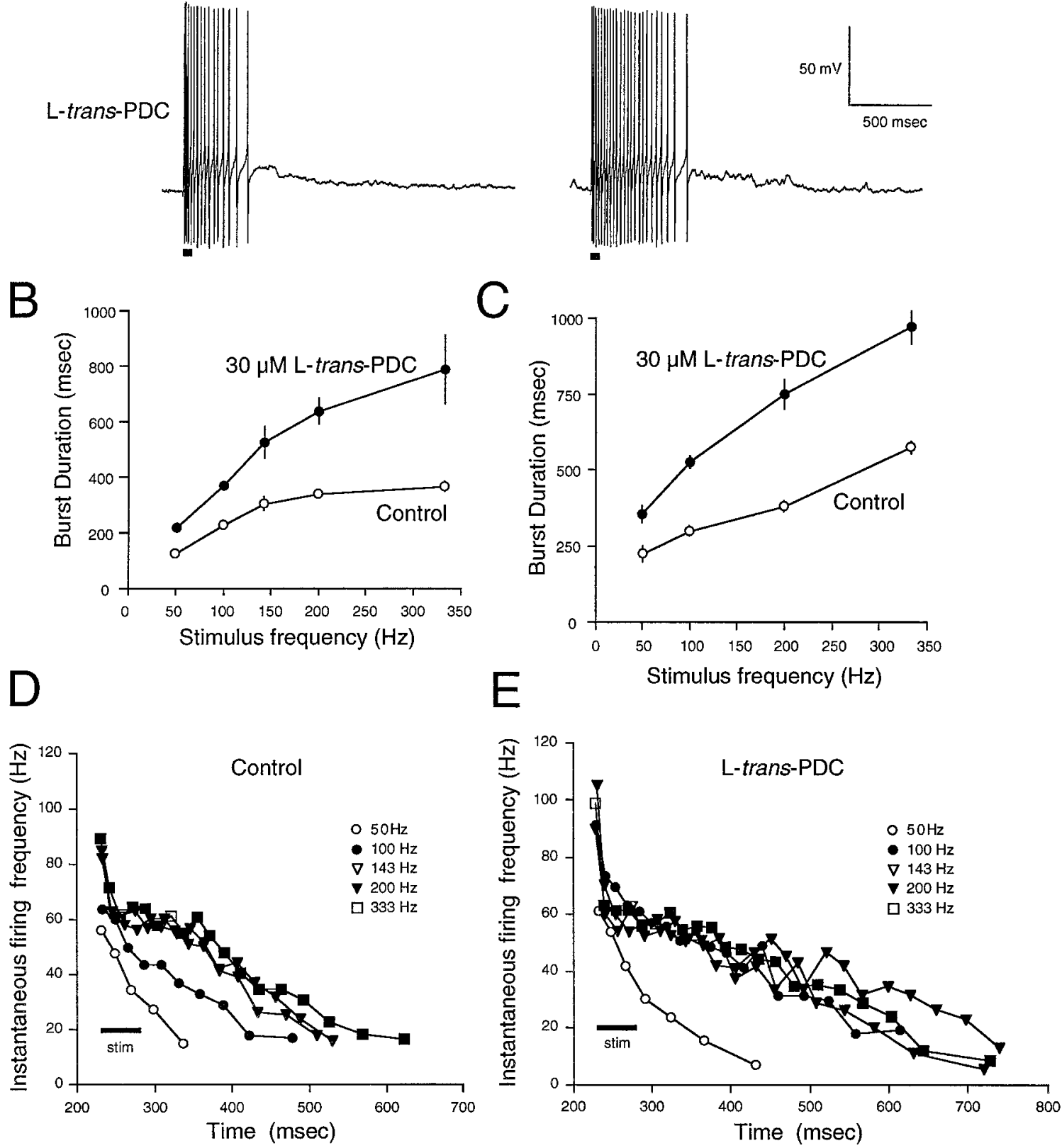

Figure 9. Effects of PDC on the firing rate evoked by repetitive synaptic stimulation. $A$, The response of a granule cell to repetitive synaptic stimulation before (top traces) and after (bottom traces) the application of PDC $(30 \mu \mathrm{M})$. Horizontal bars under each trace represent the duration of the synaptic stimulus $(50 \mathrm{msec}) . B, C$, Relation between stimulus frequency and the burst duration for two granule cells. The plot in $B$ is derived from the cell illustrated in $A$. Each point represents the mean \pm SE for five trials at each stimulus frequency. $D, E$, Changes in the instantaneous firing frequency during and after synaptic stimuli of varying frequencies before $(D)$ and after $(E)$ the application of PDC ( $30 \mu \mathrm{M})$. Data were derived from the cell illustrated in $A$ and $B$. The duration of the stimulus $(50 \mathrm{msec})$ is shown by horizontal bars. Stimulus frequencies are indicated by inset key. Instantaneous firing frequencies were measured using a threshold set at $0 \mathrm{mV}$ (to avoid counting the smaller stimulus artifacts), and measures of interspike intervals were converted to frequency using routines written in Igor. Note that, after the initial stimulus, an upper firing rate of $\sim 60 \mathrm{~Hz}$ is achieved at most frequencies of stimulation; in Control the duration of the burst systematically lengthens $(D)$, as is also shown in $B, C$, and Figure $8 D$. After the application of PDC $(E)$, the maximal firing rate after the stimulus is not enhanced, but the burst duration at all frequencies is prolonged. 
Barbour, 1997; Bergles and Jahr, 1997; Otis et al., 1997). Our failure to detect currents evoked by the application of the transporter substrates PDC or D-aspartate may indicate that the transporters that contribute to the termination of synaptic transmission are not located on granule cells. This is consistent with anatomical reports that GLT-1 and GLAST are astrocytic transporters (Lehre et al., 1995), and EAAT4 immunoreactivity is confined to the molecular layer of the cerebellum (Yamada et al., 1996). Although EAAC1 (EAAT3) mRNA has been reported to be present in granule cells (Furuta et al., 1997), it may not be expressed at levels high enough to detect transporter-evoked currents.

The finding that application of DHK does not prolong the EPSC or change the holding current suggests that the subtype of transporter underlying the effect of PDC is not GLT-1 (EAAT2). This is consistent with the finding that the GLT-1 protein is not detectable in the cerebellum until postnatal week 3, whereas GLAST is present at high levels from birth (Ullensvang et al., 1997). An alternative interpretation is that because DHK is not a transported substrate, but rather a true blocker (Arriza et al., 1994), counter-transport of glutamate out of cells is not contributing to a rise in extracellular glutamate that interacts with the glutamate transient and prolongs the EPSC. However, the GPT experiment (Fig. 3) suggests that the rise in extracellular glutamate concentration produced by PDC does not underlie its effect on synaptic transmission. Therefore, these data suggest that GLAST (EAAT1) may be the transport subtype most responsible for assisting the clearance of synaptically released glutamate, although a contribution by EAAC1 (EAAT3) cannot be ruled out.

\section{Functional significance of transporters at MF-GC synapse}

In the vestibulocerebellum, MF terminals also form giant synapses with the dendrioles of the UBC dendritic brush. Impairment of glutamate transport by $100 \mu \mathrm{M}$ PDC prolongs the decay of the AMPA receptor-mediated EPSC evoked by single stimuli at the MF-UBC synapse (Kinney et al., 1997). The hypothesis that the glial transporter GLAST contributes to the time course of synaptic currents at these two synapses suggests that glutamate diffusion from the MF and UBC synaptic cleft is influenced by transporters that are localized at relatively distant sites. Although this appears to be an unlikely scenario for glutamate released at a small number of synapses, it should be noted that each MF terminal forms up to 150 synaptic junctions with postsynaptic elements (Jakab and Hámori, 1988; Jakab 1989), suggesting that a considerable amount of glutamate is released into the interior of the glomerulus with each presynaptic stimulus. Recent modeling data suggest that intersynaptic diffusion of transmitter, i.e., crosstalk, may be significant enough to activate high-affinity receptors and desensitize others (Barbour and Häusser, 1997). The incidence of crosstalk is greater at synapses where separate postsynaptic densities share the same presynaptic terminal (Barbour and Häusser, 1997), as occurs at excitatory synapses within the cerebellar glomerulus. This suggests spillover may be an important element of information processing within the glomerulus, regulated by the localization and density of glutamate transporters. Consistent with this idea, IPSCs mediated by GABA spillover have been identified in the glomerulus, and this phenomenon is enhanced by inhibition of GABA transport (Rossi and Hamann, 1998). Future studies directed toward elucidating the functional significance of the glomerular morphology may reveal novel signal processing capabilities of this unique cerebellar structure.

\section{REFERENCES}

Arriza JL, Fairman WA, Wadiche JL, Murdoch GH, Kavanaugh MP, Amara SG (1994) Functional comparisons of three glutamate transporter subtypes cloned from human motor cortex. Neuron 14:5559-5569.

Asztely F, Erdemli G, Kullmann DM (1997) Extrasynaptic glutamate spillover in the hippocampus: dependence on temperature and the role of active glutamate uptake. Neuron 18:281-293.

Barbour B, Häusser M (1997) Intersynaptic diffusion of neurotransmitter. Trends Neurosci 20:377-384.

Barbour B, Brew H, Attwell D (1991) Electrogenic uptake of glutamate and aspartate into glial cells isolated from the salamander (Ambystoma) retina. J Physiol (Lond) 436:169-193.

Barbour B, Keller BU, Llano I, Marty A (1994) Prolonged presence of glutamate during excitatory synaptic transmission to cerebellar Purkinje cells. Neuron 12:1331-1343.

Barmack NH, Baughman RW, Eckenstein FP (1992) Cholinergic innervation of the cerebellum of rat, rabbit, cat, and monkey as revealed by choline acetyltransferase activity and immunohistochemistry. J Comp Neurol 317:233-249.

Bergles DE, Jahr CE (1997) Synaptic activation of glutamate transporters in hippocampal astrocytes. Neuron 19:1297-1308.

Bridges RJ, Stanley MS, Anderson MW, Cotman CW, Chamberlin AR (1991) Conformationally defined neurotransmitter analogues. Selective inhibition of glutamate uptake by one pyrrolidine-2:4-dicarboxylate diastereomer. J Med Chem 34:717-725.

Castagna M, Shayakul C, Trotti D, Sacchi VF, Harvey WR, Hediger MA (1997) Molecular characteristics of mammalian and insect amino acid transporters: implications for amino acid homeostasis. J Exp Biol 200:269-286

Chaudhry FA, Lehre KP, van Lookeren Campagne M, Ottersen OP, Danbolt NC, Storm-Mathisen J (1995) Glutamate transporters in glial plasma membranes: highly differentiated localizations revealed by quantitative ultrastructural immunocytochemistry. Neuron 15:711-720.

Clark BA, Barbour B (1997) Currents evoked in Bermann glial cells by parallel fibre stimulation in rat cerebellar slices. J Physiol (Lond) 502:335-350.

Clements JD (1996) Transmitter time course in the synaptic cleft: its role in central synaptic function. Trends Neurosci 19:163-171.

Clements JD, Lester RAJ, Tong G, Jahr CE, Westbrook GL (1992) The time course of glutamate in the synaptic cleft. Science 258:1498-1501.

D'Angelo E, Rossi P, Taglietti V (1993) Different proportions of $N$-methyl-D-aspartate and non- $N$-methyl-D-aspartate receptor currents at the mossy fibre-granule cell synapse of developing rat cerebellum. Neuroscience 53:121-130.

D’Angelo E, De Filippi G, Rossi P, Taglietti V (1995) Synaptic excitation of individual rat cerebellar granule cells in situ: evidence for the role of NMDA receptors. J Physiol (Lond) 484:397-413.

Diamond JS, Jahr CE (1995) Asynchronous release of synaptic vesicles determines the time course of the AMPA receptor-mediated EPSC. Neuron 15:1097-1107.

Diamond JS, Jahr CE (1997) Transporters buffer synaptically released glutamate on a submillisecond time scale. J Neurosci 17:4672-4687.

Ebralidze AK, Rossi DJ, Tonegawa S, Slater NT (1996) Modification of NMDA receptor-channels and synaptic transmission by targeted disruption of the NR2C gene. J Neurosci 16:5014-1525.

Edmonds B, Colquhoun D (1992) Rapid decay of averaged singlechannel NMDA receptor activations recorded at low agonist concentration. Proc R Soc Lond B Biol Sci 250:279-86.

Edwards FA, Konnerth A, Sakmann B, Takahashi T (1989) A thin slice preparation for patch clamp recordings from neurones of the mammalian central nervous system. Pflügers Arch 414:600-612.

Eliasof S, Jahr CE (1996) Retinal glial cell glutamate transporter is coupled to an anionic conductance. Proc Natl Acad Sci USA 93:4153-4158.

Fairman WA, Vandenberg RA, Arriza JL, Kavanaugh MP, Amara SG (1995) An excitatory amino acid transporter with properties of a ligand-gated chloride conductance. Nature 375:599-603.

Furuta A, Martin LJ, Lin C-LG, Dykes-Hoberg M, Rothstein JD (1997) Cellular and synaptic localization of the neuronal glutamate transporters excitatory amino acid transporter 3 and 4. Neuroscience 81:1031-1042. 
Gerrits NM, Epema AH, van Linge A, Dalm E (1989) The primary vestibulocerebellar projection in the rabbit: absence of primary afferents in the flocculus. Neurosci Lett 105:27-33.

Goldberg JM, Fernandez C (1971) Physiology of peripheral neurons innervating semicircular canals of the squirrel monkey. I. Resting discharge and response to constant angular accelerations. J Neurophysiol 34:635-660.

Hamill OP, Marty A, Neher E, Sakmann B, Sigworth FJ (1981) Improved patch-clamp techniques for high-resolution current recording from cells and cell-free membrane patches. Pflügers Arch 391:85-100.

Hestrin S, Sah P, Nicoll RA (1990) Mechanisms generating the time course of dual component excitatory synaptic currents recorded in hippocampal slices. Neuron 5:247-253.

Isaacson JS, Nicoll RA (1993) The uptake inhibitor L-trans-PDC enhances responses to glutamate but fails to alter the kinetics of excitatory synaptic currents in the hippocampus. J Neurophysiol 70:2187-2191.

Jakab RL (1989) Three-dimensional reconstruction and synaptic architecture of cerebellar glomeruli in the rat. Acta Morphol Hung 37:11-20.

Jakab RL, Hámori J (1988) Quantitative morphology and synaptology of cerebellar glomeruli in the rat. Anat Embryol 179:81-88.

Kinney GA, Overstreet LS, Slater NT (1997) Prolonged physiological entrapment of glutamate in the synaptic cleft of cerebellar unipolar brush cells. J Neurophysiol 78:1320-1333.

Korte G, Mugnaini E (1979) The cerebellar projection of the vestibular nerve in the cat. J Comp Neurol 184:265-278.

Lehre KP, Levy LM, Ottersen OP, Storm-Mathisen J, Danbolt NC (1995) Differential expression of two glial glutamate transporters in the rat brain: quantitative and immunocytochemical observations. J Neurosci 15:1835-1853.

Lester RAJ, Clements JD, Westbrook GL, Jahr CE (1990) Channel kinetics determine the time course of NMDA receptor-mediated synaptic currents. Nature 346:565-567.

Maki R, Robinson MB, Dichter MA (1994) The glutamate uptake inhibitor L-trans-pyrrolidine-2,4-dicarboxylate depresses excitatory synaptic transmission via a presynaptic mechanism in cultured hippocampal neurons. J Neurosci 14:6754-6762.

Matsui K, Hosoi N, Tachibana M (1999) Active role of glutamate uptake in the synaptic transmission from retinal nonspiking neurons. J Neurosci 19:6755-6766.

Mennerick S, Zorumski CF (1994) Glial contributions to excitatory neurotransmission in cultured hippocampal cells. Nature 368:59-62.

Mennerick S, Zorumski CF (1995) Presynaptic influence on the time course of fast excitatory synaptic currents in cultured hippocampal cells. J Neurosci 15:3178-3192.

Mennerick S, Benz A, Zorumski CF (1996) Components of glial responses to exogenous and synaptic glutamate in rat hippocampal microcultures. J Neurosci 16:55-64.

Min MY, Rusakov DA, Kullmann DM (1998) Activation of AMPA, kainate, and metabotropic receptors at hippocampal mossy fiber synapses: role of glutamate diffusion. Neuron 21:561-570.

O'Brien RJ, Fischbach, GD (1986) Modulation of embryonic motorneuron glutamate sensitivity by interneurons and age. J Neurosci 6:3290-3296

Olverman HJ, Jones AW, Watkins JC (1984) L-glutamate has higher affinity than other amino acids for [3H]-D-AP-5 binding sites in rat brain membranes. Nature 307:460-462.

Overstreet LS, Liu Y-B, Slater NT (1997) Glutamate transporters sculpt the timecourse of synaptic transmission in cerebellar granule cells. Soc Neurosci Abstr 23:2006.

Otis TS, Wu Y-C, Trussell LO (1996) Delayed clearance of transmitter and the role of glutamate transporters at synapses with multiple release sites. J Neurosci 16:634-1644.

Otis TS, Kavanaugh MP, Jahr CE (1997) Postsynaptic glutamate transport at the climbing fiber-Purkinje cell synapse. Science 277:1515-1518.

Patneau DK, Mayer ML (1990) Structure-activity relationships for amino acid transmitter candidates acting at $N$-methyl-D-aspartate and quisqualate receptors. J Neurosci 10:2385-2399.

Rossi DJ, Hamann M (1998) Spillover-mediated transmission at inhibi- tory synapses promoted by high-affinity $\alpha 6$ subunit $\mathrm{GABA}_{\mathrm{A}}$ receptors and glomerular geometry. Neuron 20:783-795.

Rossi DJ, Slater NT (1993) The developmental onset of NMDA receptor-channel activity during neuronal migration. Neuropharmacology 32:1239-1248.

Rothstein JD, Martin L, Levey AI, Dykes-Doberg M, Jin L, Wu D, Nash N, Kuncl RW (1994) Localization of neuronal and glial glutamate transporters. Neuron 13:713-725.

Rothstein JD, Dykes-Hoberg M, Pardo CA, Bristol LA, Jin L, Kuncl RW, Kanai Y, Hediger MA, Wang Y, Schielke JP, Welty DF (1996) Knockout of glutamate transporters reveal a major role for astroglial transport in excitoxicity and clearance of glutamate. Neuron 16:675-686.

Sarantis M, Ballerini L, Miller B, Silver RA, Edwards M, Attwell D (1993) Glutamate uptake from the synaptic cleft does not shape the decay of the non-NMDA component of the synaptic current. Neuron 11:541-549.

Silver RA, Traynelis SF, Cull-Candy SG (1992) Rapid-time-course miniature and evoked excitatory currents at cerebellar synapses in situ. Nature 355:163-166.

Silver RA, Colquhoun D, Cull-Candy SG, Edmonds B (1996) Deactivation and desensitization of non-NMDA receptors in patches and the time course of EPSCs in rat cerebellar granule cells. J Physiol (Lond) 493:167-173.

Slater NT, Kinney GA (1996) Reuptake contributes to the removal of glutamate from the synaptic cleft of rat cerebellar granule and unipolar brush cells. Soc Neurosci Abstr 22:796.

Szatkowski M, Barbour B, Attwell D (1990) Non-vesicular release of glutamate from glial cells by reversed electrogenic glutamate uptake. Nature 348:443-446.

Takahashi M, Kovalchuk Y, Attwell D (1995) Pre- and post-synaptic determinants of EPSC waveform at cerebellar climbing fibre and parallel fibre to Purkinje cell synapses. J Neurosci 15:5693-5707.

Takahashi M, Sarantis M, Attwell D (1996a) Postsynaptic glutamate uptake in rat cerebellar Purkinje cells. J Physiol (Lond) 497:523-530.

Takahashi T, Feldmeyer D, Suzuki N, Onodera K, Cull-Candy SG, Sakimura K, Mishina M (1996b) Functional correlation of NMDA receptor $\epsilon$ subunits expression with the properties of single-channel and synaptic currents in the developing cerebellum. J Neurosci 16:4376-4382.

Takahashi M, Billups B, Rossi D, Sarantis M, Hamann M, Attwell D (1997) The role of glutamate transporters in glutamate homeostasis in the brain. J Exp Biol 200:401-409.

Tanaka K, Watase K, Manabe T, Yamada K, Watanabe M, Takahashi K, Iwama H, Nishikawa T, Ichihara N, Kikuchi T, Okuyama S, Kawashima N, Hori S, Takimoto M, Wada K (1997) Epilepsy and exacerbation of brain injury in mice lacking the glutamate transporter GLT-1. Science 276:1699-1702.

Tong G, Jahr CE (1994) Block of glutamate transporters potentiates postsynaptic excitation. Neuron 13:1195-1203.

Ullensvang K, Lehre KP, Storm-Mathisen J, Danbolt NC (1997) Differential developmental expression of the two rat brain glutamate transport proteins GLAST and GLT. Eur J Neurosci 9:1646-1655.

Wadiche JI, Amara SG, Kavanaugh MP (1995a) Ion fluxes associated with excitatory amino acid transport. Neuron 15:721-728.

Wadiche JI, Arriza JL, Amara SG, Kavanaugh MP (1995b) Kinetics of a human glutamate transporter. Neuron 14:1019-1027.

Wall MJ, Usowicz M (1997) Development of action potential-dependent and independent spontaneous GABAA receptor-mediated currents in granule cells of postnatal rat cerebellum. Eur J Neurosci 9:533-548.

Wang GJ, Chung HJ, Schnuer J, Lea E, Robinson MB, Potthoff WK, Aizenman E, Rosenberg PA (1998) Dihydrokainate-sensitive neuronal glutamate transport is required for protection of rat cortical neurons in culture against synaptically released glutamate. Eur J Neurosci 10:2523-2531.

Yamada K, Watanabe M, Shibata T, Tanaka K, Wada K, Inoue Y (1996) EAAT4 is a post-synaptic glutamate transporter at Purkinje cell synapses. NeuroReport 7:2013-2017. 